\title{
KONSEP SURGA, NERAKA DAN MOKSA DALAM KAKAWIN CANDRA BAIRAWA
}

Oleh:

\author{
Ida Ayu Gde Apsari Saraswati \\ Fakultas Ilmu Agama dan Kebudayaan \\ Universitas Hindu Indonesia, Denpasar \\ apsarijelantik@yahoo.co.id
}

dan

I Gusti Agung Paramita

Harian Umum Fajar Bali, DENPASAR

agungparamita@yahoo.co.id

\begin{abstract}
The core teaching of Candra Bairawa is Catur Yoga Marga implementation in its entirety which cannot be treated separately. From the concept of catur yoga marga there raises the teaching of karma sanyasa that includes karma marga, bhakti marga, jnana marga, and yoga marga while those who only take the jnana marga and the yoga marga will give rise to the concept of yoga sanyasa teaching. These two concepts are depicted by the main character, Candra Bairawa as the sanyasa yoga, and Yudhistira as the character of karma sanyasa. Both are equally reaching the realm of moksha by releasing their spirit; Yudhistira to the realm of Shiva, whereas Candra Bairawa takes the jnana yoga marga to reach the same realm. Essencially, both are equally regarded to have Samyajnana or having the right knowledge.
\end{abstract}

\begin{abstract}
Abstrak
Inti dari ajaran Candra Bairawa adalah pelaksanaan Catur Yoga Marga secara utuh dan tidak boleh terpisah-pisahkan. Dari konsep catur yoga marga ini melahirkan ajaran karma sanyasa yang mencakup karma marga, bhakti marga, jnana marga dan yoga marga, sedangkan mereka yang hanya mengambil jnana marga dan yoga marga melahirkan konsep ajaran yoga sanyasa.

Dari kedua konsep tersebut yang diperankan oleh tokoh utama Candra Bairawa sebagai tokoh yoga sanyasa dan Yudhistira sebagai tokoh karma sanyasa sama-sama dapat memasuki alam moksa dengan melepas roh beliau, Yudhistira menuju alam Siwa sedangkan jalan yang ditempuh oleh Candra Bairawa adalah jnana marga dengan yoga marga. Pada intinya sama-sama Samyajnana, yaitu memiliki ilmu pengetahuan yang benar.
\end{abstract}

Kata kunci: Kakawin Candra Bairawa, Surga, Neraka 


\section{PENDAHULUAN}

Candra Bairawa merupakan sebuah karya sastra yang berbentuk sekar agung, yaitu kakawin. Menurut Agastia dalam bukunya Ida Pedanda Made Sidemen, Pengarang Besar Bali Abad ke-20 menguraikan bahwa Ida Pedanda Made Sidemen yang dikenal memakai nama samaran Tanarsa, Tantusta, Tanmaha adalah Pengarang Besar Bali abad ke-20 (Agastia, 1994: 1). Lebih lanjut Agastia menjelaskan ada sejumlah karya beliau yang telah dapat dipastikan, yaitu $S i$ wagama (prosa), Kakawin Candra Bairawa, Kakawin Cayadijaya, Kakawin Singhalangghyala, Kidung Rangsang, dan Geguritan Salampah Laku.

Dari penjelasan di atas, dapat dipastikan bahwa Kakawin Candra Bairawa buah karya Ida Pedanda Made Sidemen yang meninggal dalam usia yang sangat panjang, yaitu dalam usia 126 tahun - tepatnya beliau dipanggil Hyang Maha Kuasa pada tanggal 10 September 1984 merupakan salah satu karya sastra yang penting untuk memahami ajaran filsafat Hindu, terutama ajaran tentang konsep surga, neraka, dan moksa.

Konsep-konsep ajaran agama Hindu yang tertuang dalam Kakawin Candra Bairawa digambarkan dengan jelas dalam wirama-wirama yang mendukung struktur kakawin tersebut. Di satu sisi, konsep-konsep ajaran tersebut diimplementasikan oleh tokoh Yudisthira sebagai raja Astinapura yang mengajak seluruh rakyatnya melaksanakan Karma Sanyasa, yaitu jalan untuk menuju Tuhan dengan cara melakukan pelaksanaan upacara Panca Yadnya. Di pihak lain, Candra Bairawa adalah seorang raja yang memerintah di kerajaan Dewantara, juga mengajak masyarakatnya tidak ber-yadnya dalam aktivitas keagamaan, melainkan langsung menyembah Tuhan yang berstana di masing-masing individu dalam istilah Bali disebut Dewane ada di deweke, yaitu Tuhan itu ada pada diri sendiri. Candra Bairawa adalah pelaksana Yoga Sanyasa.

Sesuai dengan tujuan agama Hindu yakni untuk mencapai Jagadhita dan moksa, yaitu untuk mewujudkan kebahagiaan lahir dan batin, maka setiap umat Hindu dituntut untuk mampu mewujudkan Jagadhita dan mencapai moksa. Rupanya tidak semua orang mampu mencapai tujuan tertinggi yang berupa moksa tersebut, terlebih karena karma buruk yang telah dilaksanakan seseorang sebelumnya, maka pahala dari perbuatan itu adalah neraka, yakni berupa penderitaan di dunia dan di akhirat nanti, sedangkan bila banyak berbuat baik, seseorang akan mencapai svarga (surga) dan bahkan moksa.

Dalam kitab Sarasamuccaya (362), dijelaskan tentang orang yang mendapatkan surga, neraka, atau moksa. Sloka suci tersebut adalah berbunyi sebagai berikut:

Yan ring swargaloka, sukha kewala ikang bhinukti ngkan, kunang yan ngke ring martyaloka, sukha duhka ikang bhinukti, Kunang ring neraka loka, dhuka kewala ikang bhinukti ngkana, japwan moksapada, paramasukha ikang bhinukti ngkana.

Terjemahannya:

Jika di surgaloka, kesenangan saja yang ada di sana, akan tetapi di sini, dunia yang fana ini, suka-duka yang dialami, jika di neraka loka kedukaan belaka yang diderita di sana, sebaliknya di moksaloka, kebahagiaan terluhur yang diperoleh di sana (Kadjeng, 2005: 180).

Dari uraian di atas dapat dipahami bahwa, seseorang yang mendapatkan surga ataupun moksa, tidak ada yang lain, kecuali memahami ajaran agama, mendalami dan mengamalkannya dalam kehidupan yang nyata. Sumber ajaran yang menguraikan ajaran tersebut adalah kitab suci Veda dan susastra Hindu yang cukup banyak jumlahnya. Kakawin Candra Bairawa merupakan salah satu susastra Hindu yang dapat dijadikan pedoman oleh umat Hindu untuk memahami konsep surga, neraka, dan moksa yang tersurat dan tersirat dalam bait-bait kakawin tersebut. Namun pada kenyataannya, tidak semua masyarakat dari kalangan akademika, terlebih masyarakat awam, mengetahui ajaran-ajaran yang kemungkinan masih bersifat imanen seperti halnya surga, neraka, dan moksa yang terkandung dalam kakawin karya Ida Pedanda Made Sidemen. Alangkah baiknya teks yang mengandung ajaran suci tersebut dipelajari guna mendalami ajaran agama Hindu.

Kakawin Candra Bairawa yang memakai media bahasa Jawa Kuno sampai saat ini belum ada peneliti yang secara khusus mengkaji wacana konsep surga, neraka dan moksa Hal ini menarik perhatian penulis, karena tampaknya ada korelasi antara perilaku, pembangunan pura dan lingkungan, dan ritual umat Hindu di Bali dengan kakawin Candra Bairawa. 


\subsection{Landasan Teori}

Menurut Richard E. Palmer (2005: 16), hermeneutika memiliki tiga jangkauan makna yakni sebagai to express, to explain, dan to translate. To express memiliki arti mengatakan. Definisi ini biasa digunakan dalam lingkungan teologis. To explain yang berarti menjelaskan. Interpretasi sebagai penjelasan menekankan aspek pemahaman diskursif. Ia menitikberatkan pada penjelasan ketimbang dimensi interpretasi ekspresif. Hal yang paling esensial dari kata-kata bukanlah "mengatakan", tapi juga menjelaskan. Selanjutnya, to translate.

Pada dimensi ini to interpret (menafsirkan) juga bermakna to translate (menerjemahkan). Ketika sebuah teks berada dalam bahasa pembaca, benturan antara dunia teks dengan pembaca sendiri dapat menjauhkan perhatian. Bagaimanapun, ketika teks tertulis dalam bahsa asing, maka perbedaan perspektif dan horizon tidak lagi dibiarkan.

Tokoh terkenal yang memiliki asumsi berbeda tentang teori hermeneutika ini adalah Schleirmacher, Wilhelm Dilthey, Heidegger, dan Gadamer. Dilthey meganggap hermeneutika adalah inti disiplin yang dapat melayani sebagai pondasi bagi pemahaman seni, aksi, dan tulisan manusia.

Hemat Dilthey dalam hermeneutika disiplin yang memfokuskan pada interpretasi, yang khususnya terhadap interpretasi obyek, senantiasa bersifat historis pada sebuah teks. Martin Heidegger, memakai jangkauan hermeneutika dalam lapangan filsafat fenomenologis. Hermeneutika dipakai untuk menjelaskan keberadaan manusia secara femonenologis. Sedangkan Gadamer menganggap bahwa hermeneutika adalah pertemuan dengan Ada melalui bahasa (Palmer, 2005: 47).

Menurut Irmayanti (Kaelan, 2005: 80), hermeneutika juga bertujuan untuk mencari dan menemukan makna terkandung dalam obyek penelitian berupa fenomena kehidupan manusia melalui pemahaman dan jalan interpretasi teks. Prinsip kerja hermeneutika menurut Schleirmacher (dalam Kaelan, 2005: 80) adalah untuk menangkap objecktive geist yang terkandung dalam obyek penelitian. Objective geist juga dapat diartikan sebagai makna terdalam, hakikat nilai yang terkandung dalam objek penelitian.

Menurut Palmer (2005: 48) hermeneutika adalah sistem tafsir untuk mengungkapkan makna "tersembunyi" di balik teks. Hermeneutika adalah proses penguraian yang beranjak dari isi dan makna yang nampak ke arah terpendam dan tersembunyi. Sejalan dengan uraian teori di atas, penulis lebih merujuk pada asumsi dasar Richard Palmer mengganggap hermeneutika sebagai teori yang mengungkap makna terdalam suatu objek melalui jalan penafsiran teks.

\subsection{Metode Penelitian}

Kajian ini menggunakan pendekatan metode penelitian kualitatif. Data dikumpulkan melalui studi dokumen. Setelah data berhasil dikumpulkan, maka langkah selanjutnya adalah melakukan kegiatan analisis data. Data adalah bahan mentah yang perlu diolah sehingga menghasilkan informasi atau keterangan, baik kualitatif maupun kuantitatif.

Data yang telah memenuhi syarat perlu diolah. Menurut Bogden \& Biklen (Moleong. 2005: 248) analisis data kualitatif upaya yang dilakukan dengan jalan bekerja dengan data, mengorganisasikan data, memilah-milahnya menjadi satuan yang dapat dikelola, mensitesiskannya, mencari dan menemukan pola, menemukan apa yang penting, dan apa yang dipelajari, dan memutuskan apa yang dapat diceritakan oleh orang lain.

Data yang berhasil dikumpulkan dalam penelitian ini akan dianalisis sesuai dengan metode hermeneutik. Cara kerja hermeneutika adalah memfokuskan pada objek yang berkaitan dengan simbol-simbol, bahasa, atau pada teks-teks serta karya budaya lainnya. Bagi seorang penafsir, fenomena objek penelitian harus dilihat sebagai suatu wacana yang terbuka untuk ditafsirkan sesuai dengan konteksnya. Namun demikian setidaknya telah ditentukan, apakah objek penelitiannya berada pada lingkup objek verbal atau non verbal (Kaelan, 2005: 81)

Menurut Kaelan (2005: 81) lingkaran hermeneutik adalah semacam pola penyelidikan ilmiah untuk proses interpretasi, karena dalam lingkaran itu terdapat kategori, bagian-bagian serta unsur-unsur yang telah ditentukan peneliti. Hubungan antara kategori satu dengan yang lainnya merupakan suatu proses interpretasi. Setiap simbol atau objek verbal yang ada pada kebudayaan manusia selalu memiliki makna ganda, yaitu makna literal atau harfiah dan makna sesungguhnya. Makna yang pertama menghasilkan pemaknaan literal, sedangkan makna 
kedua yang berada di balik makna literal, merupakan makna sesungguhnya, makna yang terus dicari, diterjemahkan dan dipahami oleh si peneliti.

Di sisi lain, pada pemaknaan verbal teks harus dilihat sebagai hubungan si peneliti dan pencipta teks. Hubungan antara pencipta teks dan si peneliti menyebabkan adanya dua posisi, yaitu distansiasi dan apropriasi. Terjadinya distansiasi karena peneliti memiliki jarak terhadap teks tersebut. Peneliti akan terfokus dalam teks dan konteksnya, sehingga akan sangat berpengaruh oleh gagasan penulis teks. Pada kutub apropriasi, teks menjadi sangat terbuka oleh si penafsir dalam hal ini adalah peneliti.

Teks dan konteksnya seakan-akan terproyeksikan dalam subyek peneliti, sehingga penafsiran menjadi sangat diperkaya oleh kreativitas peneliti. Menurut Irmayanti (Kaelan, 2005: 82) pemaknaan dengan melibatkan dua kutub tadi akan membawa peneliti sebagai penafsir pada cara berpikir kritis, kreatif, dan imajinatif yang tidak terjebak pada subyektivitas yang sempit. Melalui analisis hermeneutik seperti itu, diharapkan dapat menghasilkan deskripsi mengenai wacana surga, neraka dan moksa dalam $k a-$ kawin Candra Bairawa.

\section{PEMBAHASAN}

\subsection{Wacana Surga, Neraka, dan Moksa Dalam Kakawin Candra Bairawa}

\subsubsection{Surga}

Sebelum diuraikan konsep surga dalam kakawin Candra Bairawa, terlebih dahulu akan dijelaskan beberapa lontar yang menguraikan tentang perjalanan Atman atau roh menuju surga. Lontar-lontar tersebut diantaranya Putru Pituduh Pitara, dan Putru Pasaji.

Putru Pituduh Pitara adalah sebuah lontar yang memberi petunjuk kepada roh orang yang telah di aben oleh orang yang melakukan upacara pembersihan lahir bathin dengan cara mawinten, dan dibaca di kuburan jasadnya tinggal tulang-tulangnya saja. Tulang-tulang tersebut disupit (dijepit) dengan penjepit yang disebut dengan sepit, terbuat dari bambu kuning ( $t i-$ ing gading), disusun dari tulang kepala, tangan, kaki, dan tulang-tulang lainnya seperti waktu masih hidup, ini dinamakan ngreka. Di atas tulang-tulang tersebut di taruh kwangen. Kwan- gen-kwangen tersebut di letakkan menurut penjuru mata angin, dengan jumlah kwangen 33 buah. Setelah proses ngreka tulang selesai, dilanjutkan dengan membaca Putru Pituduh Pita$r a$, sebagai berikut:

Pukulun sang déwa pitara, mangko sira pina lěpasakén

muliha sira ring swargania, aywa sira nut dalam maning něriti,

dalan kapatala òka, dalan maning érsania tutén dénira.

(1b. 1.b).

Terjemahannya:

Wahai roh yang telah disucikan (dewa pita$r a$ ), sekarang engkau telah lepas dari ragamu, kembalilah engkau ke surga, jangan engkau ikuti arah Barat Daya, arah itu menuju neraka (patala), jalan ke Timur Laut yang harus engkau lalui.

Menurut pandangan umat Hindu (Bali), bahwa arah timur laut (Ersania) merupakan perpaduan antara arah Timur dan Utara. Arah Timur (Purwa) merupakan awal terbit matahari yang merupakan sumber energi kehidupan. Arah Utara atau Uttara juga disebut Kaja atau Ka adya. Adya berarti gunung. Gunung merupakan tempat bersemayam para dewa dan roh-roh suci, oleh karena itulah surga merupakan tempat berstana para dewa dan roh-roh suci yang menempati alam atas yaitu swah loka.

Lebih lanjut dilukiskan tentang perjalanan roh menuju surga. Roh-roh yang telah diupacarai tidak serta merta mendapatkan surga, melainkan melalui beberapa pantangan yang harus diikuti. Hal tersebut dapat dilihat dalam kutipan tersebut:

... téka pwa sira ring suruwěyam, ring balé pangangěnangěnan, nggonta rěrěn, apan parerenaning hyang déwa pitara kabéh. Sah pwa sira ring balé pangangěnangěnan, téka pwa sira ring banjaran kěmbang, aywa sira mětik kěmbang, manawa kadanda dé sang widyadari, dén lumaris lampahira, téka pwa sira ring oot gonggang, aywa sira ngidékin tungtunging oot, manawa tiba sira těngahing oot, ya ta lumaris lampahira, téka pwa sira ring babahan sanga, aywa sira nogdog lawang. (1b. 1.b).

Terjemahannya : 
... Tibalah engkau di perbatasan kahyangan (suruweyam), disebuah bale peristirahatan, di sana tempat beristirahatnya para atman (dewa pitara). Setelah engkau meninggalkan bale peristirahatan itu, kamu akan sampai di hamparan kebun bunga, jangan coba-coba memetik bunga di sana, barangkali kamu akan dimarahi oleh para widyadari, berjalanlah lurus, kamu akan sampai disebuah jembatan yang goyang-goyang (titi ugal-agil), jangan kamu menginjak ujung jembatan, kamu akan jatuh ketengah-tengah jembatan, berjalanlah dengan tenang, kamu akan tiba disuatu tempat, yaitu jalan simpang siur (jalan tol bercabang sembilan), jangan menggedor-gedor pintu...

Manawa kagyat sang dorakala, Manawa sira kabancana de sang atunggu lawang, neher tinakonakena patinira, reh ira mati eling ring pasamayanira, tinuduhaken pwa sira marga de nira hyang dorakala, tuuten de nira dalan maring wisnu pada, teka pwa sira ring wisnu pada, lumaris ta sira maring kadewatan, anuli sira ring kahyangannira Hyang Wisesa, padamunung kita i rika, apan dunu nganira Hyang Dewa Pitara Kabeh, teka pwa sira ring swarga, aywa lawas denta mang dadi dewata, pitung lek pitung wengi lawasta mangher swarga... (1b. 2.a).

Terjemahannya :

Barangkali terkejut sang dorakala, kemungkinan kamu dimarahi oleh penjaga pintu, kemudian kamu akan ditanya tentang kematianmu, oleh karena, kematianmu itu sesuai dengan takdirmu, kamu diberi petunjuk oleh beliau sang dorakala, ikuti olehmu jalan menuju Wisnupada, setiba di Wisnupada, lanjutkan ke alam dewata, tibalah engkau di surganya Sang Hyang Wisesa (Tuhan Yang Maha Kuasa), berkumpullah yang engkau di sana, karena tempat itu merupakan tempat berkumpulnya para roh- roh suci (dewa pitara), setelah kamu terdiam di surga, jangan terlalu lama menjadi dewata, hanya tujuh bulan tujuh malam saja lamanya di surga. . .

Uraian naskah Putru Pituduh Pitara di atas memberikan isyarat, bahwa surga merupakan alam orang-orang subha karma, untuk mendapatkannya melalui proses yang rumit dan berliku-liku menurut petunjuk sastra di atas.
Pustaka lain, selain naskah Putru Pituduh Pitara di atas, yaitu lontar Putru Pasaji menggambarkan bahwa seseorang akan mendapat surga, apabila sanak keluarga yang ditinggalkan melakukan upacara pitra yadnya, yaitu proses pengembalian sawa wadana dan atma wadana. Sawa wadana merupakan proses pengembalian unsur panca maha bhuta ke asalnya; 1). Rambut dan bulu badan berasal dari akasa, dikembalikan ke unsur akasa; 2). Tulang, kuku, daging berasal dari pertiwi dikembalikan ke pertiwi; 3). Keringet, darah, air liur, air kencing, berasal dari apah, dikembalikan ke apah; 4). Mata, panas badan, energi, berasal dari teja, dikembalikan ke teja; 5). Nafas berasal dari wayu, dikembalikan ke bayu. Atma wadana adalah proses penyucian roh atau atma. Proses penyucian ini dinamakan nyekah.

Pada waktu upacara nyekah, berbarengan dengan pendeta yang memimpin upacara, dibacakan lontar tentang sarana dan prasarana yang boleh dipergunakan untuk upacara nyekah, ada juga yang tidak boleh dipakai untuk sarana upacara. Apabila hal itu dilanggar menjadikan atman seseorang jatuh ke neraka (papa neraka). Demikian juga sebaliknya, apabila sarana dan prasarana yang dipergunakan sesuai dengan sastra agama, maka roh atau atman seseorang akan menuju alam surga.

Konsep surga, neraka, dan moksa di dalam kakawin Candra Bairawa diwacanakan dengan beberapa metode antara lain; 1) dengan analogi atau metafora, 2) pemerian konsep, dan 3) dengan dialog antar tokoh.

Kakawin Candra Bairawa memberikan pandangan yang berbeda terhadap wacana surga, bahwa surga terletak di dalam diri setiap manusia dan para dewa juga terdapat di dalam diri setiap orang. Hal ini merupakan pemerian konsep tentang surga di dalam kakawin Candra Bairawa.

Hal ini dapat dilihat dalam kutipan kakawin Candra Bairawa (Wirama Sragdara, 9: 4) seperti berikut ini:

Śrī Déwantāra warnan yaya sira mangaran candra bairāwa nātha, tustusning mānu rakwé kulanira winuwus wrddhi tatwa sidhi, śri bajrādhāra ring twas yaśanira matêguh trus têkéng péka bharya, tan wantên déwa ring lén wa lingiran umungup munggu ring garbbha guhya. 
Terjemahannya:

Beliau maharaja dewantara dikisahkan, yang terkenal dengan nama raja Candra "Bairawa, beliau adalah trah atau keturunan wangsa manu, sangat terkenal, karena pintar tentang ilmu utama, beliau memuja Sang Hyang Budha yang dipusatkan dalam hati, sangat tekun, istri-istri dan juga rakyat beliau sangat taat, tiada lagi dewa lain selain Candra Bairawa, dewa itu berada amat rahasia di dalam hati.

Kutipan di atas mengkonsepkan bahwa maharaja Candra Bairawa sangat menekuni ajaran $B u d d h a$, termasuk istri dan seluruh rakyat $D e-$ wantara. Menurut maharaja Candra Bairawa, Tuhan (dewa) tidak berada di luar manusia melainkan di dalam diri. Hal ini memberi argumentasi bahwa, surga tidak ada di tempat lain melainkan berada di dalam diri sendiri asalkan taat dan tekun mencari beliau. Oleh karena itu, Candra Bairawa tidak mengijinkan rakyatnya mendirikan bangunan suci dimasing-masing rumah tangga. Bangunan-bangunan suci ditiaptiap rumah tangga bagi umat Hindu di Bali disebut sanggah atau pamrajan. Candra Bairawa tidak memerlukan sarana-sarana pemujaan tersebut.

Hal ini terungkap di dalam kakawin Candra Bairawa (Wirama Sragdara, 10: 4) seperti berikut ini:

Tan tūt ring déwa śimā kabuyutaningumah tan byacāré ka ring rāt, tan wédyā śarīra prati pati ginêsöng yan pêjah tan hinéman, wā lingnyān déwa ring twas ya karananing urip molahéng jroninganggā, mātì yāpwan tininggal paraniki têmahan ndyā ta mūlyéng śarìra.

Terjemahannya :

Candra Bairawa tidak merendahkan keberadaan para dewa itu sesuai dengan dresta, yang disthanakan di mrajan atau di sanggar, yang telah lumbrah dilakukan oleh masyarakat. Tidak perlu lagi memberi sarana-sarana tertentu untuk mayat langsung saja dibakar, jika mati tidak diurus. Pendapat sang raja bahwa Tuhan (dewa) bersemayam dalam hati yang menyebabkan orang dapat hidup, hanya di badan tempatnya. Pada waktu meninggal, hanya badan kasar saja yang hancur, itulah sebabnya badan kasar ini tiada penting.
Menyimak uraian di atas, raja Candra Baira$w a$ tidak bermaksud merendahkan orang-orang yang menyembah dewa di sanggar pemujaan di mrajan, dan sanggar itu tidak diperlukan lagi, sebab badan kasar ini adalah tempat bersemayamnya Tuhan. Tuhan adalah diri sendiri.

Dalam bait yang lain disebutkan bahwa, para menteri maharaja Candra Bairawa diambil dari nama-nama dewa yang bersemayam di surga, surga itu berada di kerajaan Dewantara. Para menteri beliau bernama Si Brahma, Si Wiṣnu, Si Śiwa dan termasuk nama-nama dewa lainnya yang sangat dihormati dan dipuja oleh penganut Hindu. Hal tersebut dapat dilihat dalam kutipan kakawin Candra Bairawa (wirama Sragdhara, 11: 4) seperti berikut ini:

Kéwalywa Śrī Naréndrā Jinapati winuwus ling nikang cāra bhrtya, lén pūjaning marêk Śrī Parama Guru hatur sambating wwang manêmbah, cāra Śrī Bairawātwāngaranika pinakūt himpêrī swārgga loka, si Brāhmā Wiṣnu Mahéśwara papatihira lwir catur loka nāma.

Terjemahannya :

Candra Bairawa merupakan perwujudan Sang Hyang Buddha menurut rakyat beliau, ada lagi menyebutnya dengan sebutan Sri Parama Guru, para menteri dan rakyat beliau mengambil nama-nama para dewa di surga, seperti nama dewa Brahma menjadi si brahma, dewa Wisnu menjadi si wisnu, dan $M a-$ heswara untuk dewa Siwa menjadi si maheswara.

Penjelasan di atas mengisaratkan, bahwa ajaran yang ditekuni oleh raja Candra Bairawa bersama rakyatnya adalah ajaran Buddha. Candra Bairawa disebut juga Sri Parama Guru yaitu Guru Maha Guru, guru yang tersohor dan utama. Oleh karena itulah Candra Bairawa memberikan identitas kepada seluruh rakyatnya agar menggunakan nama-nama dewa yang ada di surga.

Dalam dialog antara Werkodara dengan Si Brahma dan Si Wisnu pada waktu akan menghadap raja Dewantara, Sang Bhimasena memperhatikan setiap deretan rumah di Dewantara, tidak ada orang yang memperhatikan Sanggar Dêngên dan Sad Kahyangan. Melihat hal itu Sang Bhima bertanya kepada Si Brahma dan Si Wisnu tentang agama yang dianut oleh masyarakat $D e$ - 
wantara. Dijawab oleh kedua menteri itu, bahwa agama mereka bernama Aji Petak, artinya pengetahuan suci pemutus. Agama Aji Petak mengajarkan bahwa tidak ada lagi ajaran, tidak ada lagi sesaji di parhyangan, oleh sebab itu tidak ada lagi sanggah dêngên di setiap rumah penduduk atas perintah Sri Candra Bairawa. Berhenti berguru, berhenti mempunyai murid, berhenti mengabdi di dunia, tidak percaya akan Bhuta Kala, hanya manusia sakti saja yang diterapkan dalam diri oleh semua orang di Dewantara.

Uraian di atas dapat dilihat dalam kutipan $\mathrm{ka}$ kawin Candra Bairawa (Wirama Girisa, 3: 20) seperti berikut ini:

Sumahurika si wiṣnu ndah rêngwākna carita, angaji pêtak arānya pan limpad mêgati warah, pegati kabuyutanyān sad kahyangan nika rinūg, mari guru mari śisya māryyā déwa padha huwus.

Terjemahannya:

Si wisnu menjawab, silahkan didengarkan cerita ini, agama aji petak namanya yaitu ilmu pengetahuan maha suci, sebagai pemungkas ilmu, oleh sebab itu tidak perlu lagi mendirikan sanggah dêngên, tiada lagi yang dinamakan siwa (guru) dan sisya (murid).

Di sisi lain, yaitu dialog antara Werkodara dengan Candra Bairawa membicarakan tentang tradisi kuno yang disebut dengan Purwa Dharma Sesana. Dijelaskan oleh Bhima, bahwa tradisi kuno itu merupakan ajaran yang berasal dari ajaran bhatara Mahadewa yang sangat dijunjung tinggi oleh dewata nawa sangha, demikian juga oleh para rsi, dewa, gandharwa, dan catur loka pala, dan telah disaksikan oleh Sang Hyang Surya Candra, tradisi kuno dimaksud terkenal dengan sebutan Tri Kaya Parisudha. Tradisi kuno yang disebut tri kaya parisudha mengajarkan disetiap rumah anggota masyarakat diwajibkan mendirikan sanggar dengen, kabuyutan, dan sad kahyangan, tempat suci untuk mohon perlindungan bagi masyarakat di desa-desa.

Demikian juga masyarakat diwajibkan mengupacarai bayi untuk menyucikan mala dari yang menjelma, untuk keselamatan dikemudian hari anggota masyarakat wajib mengupacarai mayat, tujuannnya adalah untuk menyucikan atma setelah lepas dari dunia ini dan dapat kembali menuju asalnya yang sejati. Bhima menjelaskan lebih lanjut, yang diutamakan yaitu agar masyarakat wajib bhakti kepada para dewa menyuguhkan sesajen pada bhuta yang diantar oleh mantra pandita catur asrama, yaitu pandita kerajaan. Pelaksanaan upacara ini dinamakan panca yajña. Bhima kemudian menganjurkan Candra Bairawa untuk melaksanakan ajaran purwa dharma sesana tersebut.

Candra Bairawa menjelaskan, bahwa Candra Bairawa mengetahui asal-usul tentang ajaran purwa dharma sesana yang terkenal dengan ajaran tri kaya parisudha itu seperti yang telah diajarkan oleh dewa Mahadewa kepada seluruh dewata di surga dan juga kepada Krsna dan Yudhistira. Dijelaskan lebih lanjut oleh Candra Bairawa bahwa mereka yang mengikuti ajaran tri kaya parisudha karena semata-mata takut kepada Kresna dan Yudhistira, masyarakat takut untuk tidak mengikuti Kresna dan Yudhistira karena kedua raja tersebut sangat sakti.

Masyarakat yang mengikuti ajaran Kresna dan Yudhistira itu sesungguhnya tidak tahu dengan apa yang disebut Karma Sanyasa. Tidak tahu hakikat mengapa orang menyembah arca dan kabuyutan, walaupun begitu mereka menyembah-nyembah juga. Setiap ada anggota masyarakat yang tidak berlaku demikian dibuatkan dalih bahwa hakikat dari Sad Kahyangan sesungguhnya ada pada diri setiap orang.

Pernyataan raja Candra Bairawa di atas dapat dilihat dalam kutipan kakawin Candra Bairawa (wirama Prttwitala, 1: 36) seperti di bawah ini:

Kunang nrpati Candra Bairawa muwah ngucap sārjjawa, A Um kita narārya panghuluni sang nrpéng hastina, awas nghulunangawruhé sawinuwus ta mangké yyarku, bhatara guru nāma purwanikanang wedyā n tinūt.

Terjemahannya:

Kemudian sang prabhu Candra Bairawa berkata dengan lemah lembut, baiklah cucuku Werkodara yang merupakan utusan Hastinapura, apa yang cucu katakana padaku aku memahaminya dengan betul, inti sari ajaran Śiwa yang utama itu yang patut diikuti.

Dalam kutipan berikut, raja Candra Bairawa bukan pengikut Siwa melainkan sebagai wujud Guru sejati di dunia. Kutipan tersebut termuat dalam wirama Prtwitala, 2: 36 adalah sebagai berikut ini:

Nghulun guru ngaranku dénika tinūt sasénā 
dulur, wênangku magawé parākrama mari bhūmi Déwantara, tahāngku ayuning ujar ta matupis kabéhnyān salah, ri tingkahagawe ta pāryanganumah bhațaréniwö.

Terjemahannya:

Aku merupakan guru bagi mereka yang mengikuti ajaranku, aku berhak membuat apa saja di wilayahku sendiri, jika aku pikirkan kata-katamu hanya sedikit benar kebanyakan salah, tentang keharusan bagi orang membuat kahyangan untuk para dewa.

Dari kutipan di atas menandakan bahwa raja Candra Bairawa sangat berkeberatan disuruh membuat tempat suci atau kahyangan oleh Bhima untuk mengikuti ajaran dari Kresna dan Yudhistira. Candra Bairawa bahkan mengatakan, jika mengikuti petunjuk Kresna dan Yudhistira akan menjadikan masyarakat bingung, karena dewa yang disembah tidak akan pernah dilihat dengan kasat mata.

Kutipan berikut dapat dilihat dari wirama Prtwitala, 3: 36 adalah seperti berikut ini:

Awas pwa magawé prapancani manah mungöng yan tinūt, maréng dwarawati wwangagya pitumūt têkéng astina, tumūt wwangatumūt ndatan wruhi wêkas sinêmbah tumūt, tumūtnya kawêdhin dinaṇdhaya duméh diné sang prabhu.

Terjemahannya :

Sudah pasti membuat pikiran bingung jika aku mengikuti, masyarakat di Dwarawati dan Astina pasti segera mengikuti, mereka itu ikut-ikutan, sesungguhnya mereka tidak paham apa yang disembahnya, mereka mengikuti karena ada perasaan takut, takut disalahkan oleh penguasa.

Lebih lanjut Candra Bairawa menjelaskan bahwa, mereka yang menyembah arca dan $\mathrm{Ka}$ buyutan tidak tahu hakikat dari Sad Kahyangan, bahwa kahyangan atau surga para dewa berada pada diri seseorang, dan mereka-mereka itu tidak mengetahui tujuannya sembah. Siapa yang dipuja dan siapa yang memuja. Sesungguhnya tidak ada dewa di Prasada (bumi), demikian pula di Meru, dan juga di Kabuyutan. Sesungguhnya Sunya atau "kosong" itulah yang dibuatkan arca perwujudan, diceritakan sebagai wujud dewa dengan kayu cendana, selanjutnya dibuatkan bantên, disakralkan oleh orang banyak. Padahal tidak ada dewa yang bersabda agar dibuatkan bantên, bila suatu ketika pembuatan bantên itu dihentikan, juga tidak ada dewa yang lemah lesu karena tanpa bantên.

Untuk lebih jelasnya kutipan di atas dapat dilihat dalam kutipan kakawin Candra Bairawa seperti berikut ini:

Wwanganyasa nganêmabahārcca śila pāryyangan déwata, taman wruha ri sang manêmbah aparan sinêmbah pinét, ri Paryyangan nikéng śarīra ya winéh wruhéng paryyangan, hyanging Kabuyutan syapéka ya winéh wruhéng déwati. (Wirama, Prtwitala,4: 36).

Terjemahannya:

Masyarakat yang menyembah arca batu kahyangan tempat pemujaan untuk para dewa, yang menyembah tiada mengetahui apa yang mereka sembah, kahyangan yang terdapat di dalam diri sendiri yang harus diketahui oleh para raja, dewa yang ada di pura, siapa yang tahu dewa siapa yang menerima persembahan.

Dalam kutipan selanjutnya dijelaskan sebagai berikut:

Swa jātini bhațara tan hana katon rikéng paryyangan, cinitra suradāru ārcca winangun sakarêp tinūt, pingit-pingitêning swadésa cinarun sinêmbahtêpêt, pinujaśiwāstutinujari kékaminnugrahên". (Wirama, Prtwitala, 5: 36). Terjemahannya:

Sesungguhnya dewa yang disembah di pura tidak diketahui, pohon majagau diukir seperti arca mengikuti keinginan pembuatnya, di desa pakraman sangat dikeramatkan, selalu dibuatkan caru dan disembah-sembah, menghaturkan puja Śiwastawa, doanya untuk mendapatkan anugerah.

Candra Bairawa menjelaskan bahwa, di kerajaan Dewantara tidak pernah melaksanakan upacāra Bhuta Yajna. Masyarakat Dewantara tidak tahu apa yang disebut dengan caru, sesajen untuk para bhuta menurut orang-orang Dwarawati dan Astina. Kesimpulannya bahwa di kerajaan Dewantara tidak mengenal yang namanya bantên dan segala bentuk upacāra persembahan.

Menyimak uraian kakawin Candra Bairawa di atas dapat dianalis, bahwa seluruh masyarakat 
Dewantara yang rajanya adalah prabhu Candra Bairawa mengajarkan pada rakyatnya untuk mencari surga dalam diri sendiri dengan meningkatkan spiritualitas dan kemampuan yoga yang sungguh-sungguh. Segala sarana dan prasarana pemujaan dan persembahan baik berupa membangun sanggah, mrajan, pura, sad kahyangan, meru, arca, dan segala bentuk upacāra yajña tidak diperlukan oleh Candra Bairawa dan pengikutnya, bahkan seluruh petinggi di Dewantara menggunakan nama sesuai dengan nama dewata nawa sangha yaitu sembilan dewa yang dipercaya oleh umat Hindu sebagai penjaga arah mata angin, dan atau dewa asta loka pala, yaitu delapan dewata penjaga penjuru dunia tanpa dewa Siwa sebagai sentralnya.

Surga tidak disebutkan secara implisit dalam kakawin Candra Bairawa, tetapi bila diikuti alur kakawin tersebut kata Surga berpadanan dengan kata "Kahyangan". Kahyangan berasal dari kata Hyang artinya tempat yang dimuliakan sebagai tempat suci untuk memuja Hyang Widhi (Tuhan) dan sebagai istananya para dewa. Tempat suci agama Hindu selain disebut pura juga disebut dengan kahyangan atau parhyangan, sanggah atau pemrajan. Pura merupakan perwujudan yang bersifat wahya (tampak) dari Kahyangan (surga) yang bersifat diatmiaka atau niskala. Pemerian konsep surga dalam kakawin Candra Bairawa diistilahkan dengan berbagai macam istilah, seperti kata kahyangan, pura, meru, yang merupakan refleksi nyata dari surga yang sesungguhnya.

Dari uraian di atas dapat dianalisa bahwa Candra Bairawa mengajak rakyatnya menuju surga dengan jalan yoga sanyasa, sedangkan Kresna dan Yudhistira mengajarkan masyarakat Dwarawati dan Astinapura melaksanakan upacāra agama dengan yajña yang meliputi panca yajña, dan juga setiap masyarakat membuat sanggar pemujaan, arcca, pura untuk memuja Tuhan, para dewata dan roh-roh suci leluhur termasuk unsur-unsur bhuta di dalamnya dalam usaha menuju jagadhita dan surga bahkan moksa.

Menyimak uraian di atas, dapat dianalisis tentang wacana surga dalam kakawin Candra Bairawa, yaitu melalui analogi atau metafora, melalui dialog antar tokoh dalam cerita, serta pemerian konsep. Perlu dijelaskan bahwa, wacana konsep surga secara analogi atau metafora maksudnya adalah wacana surga berdasarkan kias (persamaan atau persesuaian sebagaian dari dua benda atau hal yang berlainan (Poerwadarminta, 1996: 40). Demikian pula dengan metafora, yaitu pemakaian kata-kata bukan arti yang sebenarnya melainkan sebagai lukisan yang berdasarkan persamaan atau perbandingan (Poerwadarminta, 1996: 648). Istilah-istilah surga di dalam kakawin Candra Bairawa ada yang disebut dengan swarga, adapula kiasan lain seperti kata loka, laya, pura, bhawana dan kahyangan. Baik kata loka, laya, pura, bhawana, ataupun kahyangan memiliki arti kias sebagai surga (swarga).

Hal ini dapat dilihat dalam kutipan seperti berikut ini:

Hatur padmāningambara ta gumawang tan palayanan, ikā lwirning swārggā laya sahidêring dhiknawapada,kunang pārnnah sang wring pati ri sêlaning déwata sangha,umah mās ratnābhāswara sahidêring méru maruhur (KCB, 8: 108).

Terjemahannya:

Bagaikan bunga teratai yang tumbuh di langit tiada ujung dan pangkalnya, itu bagaikan surga berkeling tempatnya kesembilan dewata di surga, dan juga merupakan tempat (surga) dari orang yang mengetahui ajal kematiannya, bertempat diantara surganya sembilan dewa tertinggi, surga yang bermutukan intan dan mirah permata dikelilingi dengan meru yang menjulang tinggi.

Uraian di atas dapat dianalisis, bahwa penggunaan wacana surga dapat dilihat dalam kalimat "ikā lwirning swārggā laya sahidêring dhiknawapada", yang terjemahan, itu bagaikan surga melingkar tempat kesembilan dewata di surga.

Kutipan lain menjelaskan, bahwa surga juga disebut dengan pura. Hal ini dapat dilihat dari kutipan seperti berikut ini:

Nahan lwirning déwālaya ta waluyan Pāndututanaya, umor prāpténg Windwāpura ri sêlaning tāraka maya, katon tang padmā nindi ta gṛha bhațāréśwara guru, pri dondī sang nandīśwara sangamahākāla subhaga.

(KCB,10:108).

Terjemahannya:

Demikianlah jajaran dewata di surga, kemba- 
li dikisahkan sang Yudhistira, terbang menuju alam yang disebut windupura, tempat itu berada di antara sela-sela bintang, dilihatnya bunga tunjung yang tidak dapat diucapkan keindahannya, itu adalah surganya Sanghyang Mahaguru (Siwa), yang menjaga pintu bernama Sang Nandiswara dan Sang Mahakala yang terkenal.

Kata Windupura berarti alam windu, yaitu alam sunyi, tempat itu merupakan surganya Bhatara Mahaguru.

Wacana surga selanjutnya dapat dilihat dari kutipan berikut:

Ulih sang satyā çanthika pangapiting Iswara pada, ulih sang çāstrājñeng kawi pangapiting Brāhma bhawana, ulih sang nìtī ngkéçwara ngapiti mādéwa bhawana, ulih sang wīrājñāsmara ngapitikang Wișnu bhawana.

(KCB,9,108).

Terjemahannya:

Pahala dari orang yang setia dan teguh dalam hati, surganya di antara surga dewa Iswara, surga bagi sastrawan berada dia antara surga dewa Brahma, surga untuk orang yang berani mati di medan perang, surganya di antara surga dewa Wisnu.

Uraian di atas memberi kias pada wacana surga dengan kata pada dan bhwana. Wacana surga lainnya dapat dilihat dalam bentuk dialog, yaitu dialog antara Yudhistira dengan Bhatara Guru. Hal ini dapat dilihat dari kutipan seperti di bawah ini:

Kitamet Candra Bairawa pitara sang matya ringayun, kenep ring sapta sunya ta ri wekasing byoma lumeyep, atistis Surya Candra mata kateke riryyanuluhi, marangka lakwan ta mriha katemu denta gya uripa (KCB, 13: 110).

Terjemahannya:

Ananda mencari atmanya Candra Bairawa yang meninggal di medan pertempuran, atmannya bersembunyi di sapta sunya di tepi langit yang sangat rahasia, lembut sinar surya dan lembutnya cahaya bulan saja yang menyinari wilayah itu, silahkan ananda berjalan carilah dengan sungguh-sungguh, pasti ananda dapatkan dan segeralah Candra Bairawa hidup kembali.
Dari uraian di atas dapat disimpulkan bahwa, wacana konsep surga dalam kakawin Candra Bairawa diwacanakan melalui pemerian konsep, analogi atau metafora dan juga dengan dialogis atau dialog antar tokoh dalam kakawin Candra Bairawa.

\subsubsection{Neraka}

Wacana neraka di dalam kakawin Candra Bairawa disampaikan dengan analogi (metafora), dialog dan pemerian konsep. Sebelum diuraikan berdasarkan analogi, dialog, dan pemerian konsep tentang neraka, terlebih dahulu dijelaskan tentang konsep neraka dari beberapa sumber tertulis seperti;

Atharvaveda (II.14.3,V.19.1) menggambarkan bahwa, neraka sebagai rumah yang tempatnya di bawah, tempat tinggal hantu-hantu wanita, dan tukang-tukang sihir. Tempat itu disebut nerakaloka (Titib, 2006: 97). Nerakaloka merupakan tempat yang sangat bertentangan dengan suargaloka, yang merupakan tempat tinggal dewa Yama. Dalam kitab suci tersebut di atas diganbarkan, neraka sebagai tempat yang sangat dalam penuh kegelapan (VIII.2.24) atau sebagai tempat yang gelap dan hitam pekat.

Dalam kakawin Candra Bairawa juga terdapat pandangan tentang neraka tersebut. Sama halnya dengan surga, menurut raja Candra Bairawa baik surga ataupun neraka letaknya pada diri sendiri tidak ada dewa yang bersemayam di surga, juga tidak ada gunanya menghaturkan sesaji kepada dewa yang dipuja. Neraka di dalam kakawin Candra Bairawa dapat dilihat dalam dialog Werkodara dengan Candra Bairawa, bahwa neraka diistilahkan dengan $p \bar{a} p a$.

Hal ini dapat dilihat dalam kutipan Wirama Prtwitala, 15: 40 seperti berikut ini:

Manahku maparab-parab iribirib ta yā saswata, ndatan karana papa yan salah haran kaniș̣te nucap,kulanta sira ngūni yār sama haran sucitrānggadā, dhinandha pêjah diné salah haran wa ling déwata.

Terjemahannya :

Menurut pandanganku memberi nama hanya mirip tidak ada yang sama seterusnya, tidak akan berakibat neraka jika salah nama, paling-paling disebut jelek, leluhurmu pada jaman dulu kala sama namanya dengan Sucitranggada, dikenakan hukuman didenda dan dilecehkan karena namanya salah me- 
nyamai nama dewata.

Dialog dalam kutipan di atas adalah dialog Werkodara sebagai duta Kresna dan Yudhistira dengan Candra Bairawa. Dialog tersebut menyangkut nama-nama para petinggi di Dewantara mempergunakan nama-nama dewata asta loka pala, seperi Brahma, Wiṣnu, Mahéśwara, Rudra, Mahādewa, Sangkara, Sambhu, dan Iśwara.

Dalam kutipan kakawin Candra Bairawa lainnya, dijelaskan oleh raja Candra Bairawa kepada Bhima tentang asal-usul agama yang dianut oleh seluruh warga negara di Dewantara. Ajaran suci yang dijadikan pegangan pokok oleh masyarakat Dewantara bernama Bhajradhara. Yang dipuja adalah Sang Hyang Adhi Budha, mempergunakan sedikit upacāra kurban, sebab Sang Hyang Widhi ada pada diri sendiri. Dalam diri setiap orang sudah tersedia banyak sarana persembahan yang bersifat rahasia, sebagai pahala dari mengetahui sumber menjelma dan jalan kelepasan untuk menuju moksa atau nirwana.

Uraian di atas dapat disimpulkan bahwa Candra Bairawa mempercayai adanya neraka, hanya saja neraka itu tidak jauh dari diri sendiri, baik surga ataupun neraka tidak menjadi tujuan utama di dalam keyakinan Candra Bairawa, melainkan manunggal dengan Sanghyang Addhi Budha.

Neraka juga dikonsepkan dengan istilah kirana pada, yaitu tempat gelap tanpa sinar. Hal tersebut dapat dilihat dalam kutipan sebagai berikut:

Byatītan prāptāngantaka lari ni sang Pān, du tanaya, sumêngkā mör prapténgkana ri tataning kirañapada, sêlaning sūryā cāndra maliniha tan swārggha racana, pamuktyan sang çantā brata suphalaning çila rahayu (KCB, 7: 108).

Terjemahannya:

Tidak diceritakan, sampailah sang Yidhistira pada tempat orang meningggal, matahari dan bulan sangat gelap sama sekali berlawanan dengan surga, surga indah adalah pahala dari orang yang melakukan brata atau pengendalian diri untuk selalu menjaga perdamaian dunia, itu diperoleh berdasarkan perilaku yang sangat baik.

Berdasarka uraian neraka tersebut di atas dapat disimpulkan bahwa, wacana neraka dalam kakawin Candra Bairawa disampaikan melalui dialog, analogi dan pemerian konsep. Selanjutnya akan dijelaskan tentang ajaran moksa yang tersirat di dalam kakawin Candra Bairawa.

\subsubsection{Moksa}

Jendra (2008: 302) menjelaskan bahwa, kata moksha dari kata moha dan ksa yang 'bebas, tidak terikat, merdeka ( $k s a$ )' dari moha,' kelobaan, keterikatan, keinginan, kegilaan." Lebih lanjut dijelaskan, bahwa moksha berarti kesadaran diri manusia dengan Tuhan, sehingga timbul sifat: suka tanpa wali duka, "suka yang tidak pernah kembali duka, atau amor ring acintya, dan di Jawa disebut "manunggaling kawula lan Gusti", semuanya memiliki makna leburnya atman dalam persatuan dengan Tuhan. Menurut ajaran Hindu, bahwa moksha dapat dibedakan menjadi dua jenis, yaitu: 1) Moksha semasih hidup; 2) Moksha setelah meninggal.

Moksha semasih hidup sering disebut jiwa mukti. Orang yang moksha semasih hidup adalah orang yang telah mempunyai sikap yang kuat bahwa antara suka dan duka, untung dan rugi, panas dan dingin, kehidupan dan kematian, pujian dan celaan, musuh dan teman, kerikil dan intan sama tidak ada perbedaan. Mereka tidak terikat lagi kepada dunia yang maya ini. Dapat disimpulkan bahwa bebas dari keterikatan dapat disebut jiwa mukti, atau moksha semasih hidup di dunia ini. Moksha setelah meninggal adalah penyatuan kesadaran jiwa atman dengan kesadaran Brahman, tidak mesti badan kasarnya atau mayatnya hilang, tetapi kalau menghilang sangatlah baik.

Moksha ditinjau dari keberadaan badan atau mayat diyakini dapat dibedakan sebagai berikut ini: 1) Moksha yang masih meninggalkan badan kasar; 2) Moksha yang sewaktu meninggal badan kasarnya hilang tidak berbekas.

Di dalam kehidupan setelah matipun, moksha dapat dibedakan menjadi empat tingkat spiritual sebagai berikut : 1) Salokya, adalah tingkatan spiritual bhakta yang mendapat kesempatan satu daerah dengan Tuhan, umpamanya sama-sama satu banjar dengan Tuhan, 2) Samipya, adalah tingkatan spiritual bhakta yang mendapat anugrah menjadi dekat dengan Tuhan. Keadaan itu dapat diumpamakan seperti seorang pembantu (para bhakta) dengan majikannya (Tuhan), 3) Sarupya, adalah tingkatan seorang bhakta dengan Tuhan yang sudah sangat mirip, ibaratnya seperti seorang putra dengan ayahn- 
ya, 4) Sayujya atau ekanta mukti, adalah tingkatan seoarng bhakta yang telah menyatu, manunggal antara penyembah dengan yang disembah. Keadaan ini sudah mencapai "Amor ring Acintya, atau manunggaling kawula lan Gusti. Kesadaran manusia telah lebur menjadi satu dengan Brahman (Jendra, 1997: 47-50)

Selain itu masih ada tingkatan mokhsa yang lain, bila diteropong dari sudut pandang yang lain. Tingkatan moksha dimaksud adalah: 1) Moksha, adalah tingkat menunggalnya kesadaran manusia dengan Tuhan. Seseorang yang seperti ini, dia belum tahu hari dan tanggal kematiannya. Dia masih berbentuk mayat; 2) Adimoksa, adalah bila seseorang tahu hari dan tanggal kematiannya, tetapi jika meninggal masih meninggalkan mayat; 3) Paramamoksa, tingkatan ini adalah bila seseorang mengetahui hari dan tanggal kematiannya dan jika meninggal mayatnya tiada berbekas.

Dalam kakawin Candra Bairawa istilah moksha disebut dengan sunya, kelepasan, atau nirwana. Bahwa, moksha dapat dicapai dengan melaksanakan ajaran yoga sanyasa. Yoga berasal dari kata $y u j$, artinya menghubungkan diri secara langsung tanpa sarana dan prasarana kehadapan Tuhan Yang Maha Kuasa. Untuk lebih jelasnya kutipan kakawin tersebut dapat dilihat dalam wirama Bhumiramya (15-19: 82), dialog antara prabhu Kresna dengan Candra Bairawa, dijelaskan seperti berikut ini:

Nahan ika wuwus narāryya Krṣna, sira narapati Bairawā śrumojar, prabhu patanya mêné swa karmmani ngwang, wruha ta kita nihan gatingku ring rāt.

Terjemahannya:

Seperti itu pertanyaan beliau prabhu Kresna, sang prabhu Bairawa segera menjawab, sekarang anda menanyakan swakarma (perbuatan seseorang) yang saya laksanakan, supaya anda mengetahui, seperti ini caraku di dunia ini dalam menjalankan ajaran agama.

Nghuluniki sajagat ku maprawrtti, adiniki Jinapākșa tan anoli, lagi katêka-têkéng swa cara brtya, aku pinaka gurunya wéh pralīnā.

Terjemahannya:

Aku ini berbuat di dalam kerajaanku, intinya Budha Paksa tiada yang menandingi, sekarang anda menanyakan swakarma saya, saya adalah guru (Tuhan) di dunia dan sampai mempralina (mengembalikan ke asal mula).

Hana pawêkas wêkasku ring bḥrtya, suragaṇa numahöm hanéng śarīra, angaji Pegat ikī ngaranya śuddha, ri pêgati pawarah mamī rikang wwang.

Terjemahannya:

Aku memberi petunjuk kepada rakyatku, para dewata berada dan berkumpul di dalam diri, angaji Putus nama ajarannya yang maha suci, untuk menuju Moksa ajaran itu, demikian petunjukku kepada rakyat Dewantara.

Dalam kutipan 18:82 dijelaskan sebagai berikut:

Nghulunaniwi bhatāra ring śarīra, sira pinaka guru pratișta ring twas, smrtinira Śrī Bajradhāra nāma, mari guru mari śisya déwa bhūta.

Terjemahannya:

Aku menyembah Tuhan yang bersemayam dalam diriku, beliaulah guru yang langgeng tempatnya dalam hati, ketahuilah olehmu (Kresna) Beliau adalah Sri Bajradhara, tiada perlu guru dan juga murid, tiada dewa dan tiada bhuta.

Nihaniki karanangku tan prawrtti, tanarêpaku ri pāryyangan bhatāra, apanana tuhu déwa ring śarīra, sira amagêhakên urip wisāta.

Terjemahannya:

Itulah sebabnya aku tidak membuat sanggar pemujaan, tidak membuat Sad Kahyangan untuk menyembah Dewa, karena Dewa (Tuhan) berada dalam diri sendiri, beliaulah yang memberi hidup selama di badan.

Setelah prabhu Kresna mendengar penjelasan prabhu Candra Bairawa seperti itu, kemudian Kresna melanjutkan pertanyaannya tentang di mana tempat yang paling utama untuk melaksanakan yoga. Hal itu dijawab oleh prabhu Candra Bairawa dalam kutipan (Wirama Dyuta Wilambhita, 1: 84)

Nahanujar naranātha Bairawārūm, sinahuran ri sirang naréndra Krṣnnā, e naranatha wiśuddha kawruhan ta, ringapan sthana mūlyaning mayoga.

Terjemahannya:

Demikianlah jawaban prabhu Bairawa sangat lembut, dijawab oleh prabhu Kresna, wahai 
raja Dewantara, amatlah suci kata-katamu, di mana tempat yang utama untuk melakukan yoga.

Sahuri naranātha Bairawojar, prabhu diné wruha ri prayoga sanghyang, upati pūrwwaka maswadéha ring twas, ri kucuping praña nirbbhanātma śūnya. (2: 84).

Terjemahannya:

Prabhu Candra Bairawa kemudian menjawab, wahai prabhu Kresna, patut diketahui tempat manunggalnya dewata, utpeti (menciptakan) itu yang pertama, kemudian laksakan yajna di parhyangan pada diri, di kuncupnya prana (jantung) itulah tempat yoga yang maha sunyi (maha nirbhana).

Mendengar jawaban prabhu Candra Bairawa seperti itu, kemudian sang prabhu Kresna mempertontonkan kesaktian beliau dihadapan Candra Bairawa. Kesaktian itu bernama "Maha Manggala" yang tiada tandingnya. Kresna berwajah seram dan angker dan menakutkan, ini disebut dengan "Tri Wikrama", dengan menampkkan diri berkepala lima bertangan seribu, bagaikan Mahakala.

Hal ini dilukiskan dalam Wirama Dyuta Wilambhita, 6:84 seperti di bawah ini:

Krama sira krura rūpa bhīna wriddhi, lima śirahnya sahaśra bāma kāra, tuwinagöngaruhur kadìrgghya pādha, kadi Mahākala tulya méru ring göng.

Terjemahannya:

Kresna kemudian melakukan Tri Wikrama sangat seram berubah wujud, berkepala lima dan bertangan seribu, benar-benar tinggi besar hingga ke angkasa, bagaikan Sang Hyang Mahakala, seperti gunung yang tinggi besar perumpamaannya.

Hal tersebut di atas dilihat langsung oleh Candra Bairawa, tetapi Candra Bairawa malah mengatakan tontonan itu hanya mempertunjukkan kesaktian, agar orang yang bodoh supaya takut melihat kejadian itu, di samping itu Kresna dianggap membuat cela di alam tiga (bhur, buwah, dan swah loka). Bairawa terus menerus mencela Kresna, kemudian Kresna memperlihatkan kesaktian yang disebut Asta Aiswarya atau Asta Maheswara Pradipta, meliputi: Anima, Laghima, Mahima, Prakamya, Wa- sayitwa, Wasitwa, dan Prapti.

Setelah Kresna mengambil wujud seperti sedia kala, kemudian Candra Bairawa memperlihatkan kesujatian ajaran Budha yang penuh dengan pesona cinta kasih. Candra Bairawa memperlihatkan kemampuan yang sempurna untuk dapat menuju kelepasan, ajarannya itu dinamakan Brahma Ardha Nareswari.

Hal ini dapat dilihat dalam kutipan kakawin Candra Bairawa (Wirama Wimala, 4: 86) seperti berikut ini:

Rêp-rêp dhyam sang naranāthā jinātma, ogsākarāṇā sira ngānindya warṇa, sāksāt spātika sahaștā lwa tūmāp, sūryya cāndrā tuwi māsor ya kasrang.

Terjemahannya :

Bairawa kemudian bersemedi memuja bhatara Budha di dalam dirinya, tiba-tiba Candra Bairawa berubah wujud tiada tandingnya, seperti permata (manik banyu) putih lembut lebarnya satu hasta memenuhi tempat, sinar matahari dan sinar bulan dikalahkan oleh sinarnya permata manik banyu itu.

Dari kejadian tersebut beruntuhanlah hujan bunga dari surga, seluruh penghuni surga seperti dewa rsi ghana dan sapta pandita, Sang Hyang Indra, Sang Hyang Catur Loka Pala menghaturkan sembah sujud kehadapan Sang Adhi Buddha, seperti kutipan kakawin di bawah ini:

Puspā warșāntu mibéngantarikșa, sakwéh dewārsighañà sapta paṇ̣̂hya, mwang déwarāja catur loka sangghya, māstungkāra lwiri Sang Budha Mürthi (Wirama Wimala,7: 86).

Terjemahannya:

Hujan bunga berjatuhan dari angkasa, seluruh penghuni surga seperti rssighana dan sang sapta pandita, disertai pula oleh dewa Indra dan dewa Catur Loka Pala, sembah sujud menghaturkan bakti kehadapan Candra Bairawa dalam wujud Buddha.

Setelah prabhu Kresna menyatakan kalah kepada raja Candra Bairawa, karena Kresna tidak mengetahui ajian yang dipergunakan oleh Candra Bairawa, selanjutnya Kresna melaporkan hal tersebut kehadapan Maharaja Yudhistira. Sebelum Kresna melaporkan kejadian itu kepada $\mathrm{Yu}$ dhistira, Candra Bairawa berpesan kepada Kresna, jika Candra Bairawa kalah dalam mengadu 
ilmu pengetahuan dengan Yudhistira, maka putri Candra Bairawa yang bernama Diah Ratna Sasangka yang menjadi taruhannya. Diah Ratna Sasangka adalah permata kerajaan Dewantara. Pesan itu dilaksanakan dengan baik oleh prabhu Kresna. Tiada terceritakan datanglah raja Yudhistira, di tempat raja Candra Bairawa. Candra Bairawa menyambut dengan ramah kedatangan Yudhistira dengan menyebut perwujudan Bhatara Dharma, sebagai bapak ibu seluruh dunia, tekun menjalankan ajaran Tri Kaya Parisudha. Candra Bairawa menyapa sesuai dengan kutipan Wirama Wangsastha, 3: $98 \mathrm{sep}$ erti di bawah ini:

Mojar ta sang Śrī nrpa Bairawa prabhu, kamung Narendrā ratu Hastineśwara, sāksāt bhatareśwara siddhi dharmawān, paniwyaning śāsana dharma Sang Wiku.

Terjemahannya:

Bersabda prabu Candra Bairawa, wahai raja Hastinapura, engkau bagaikan Sang Hyang Iswara sidhi dan sangat dharmawan, Dihormati oleh para wiku yang melaksanakan ajaran dharma.

Candra Bairawa menyuruh Yudhsitira mempergunakan ajaran Siwa Tattwa, dan keutamaan kepanditaan yang dimiliki oleh Yudhistira. Kemudian Yudhistira memasang ajaran yang bernama Asta Lingga, lengkap dengan Mudra (sikap dan gerakan-gerakan tangan) lengkap dengan semua aksara. Setelah Yudhistira mengkonsentarasikan diri beliau pada Panca Windu, di Puncak Asta Lingga, kemudian Yudhistira memisahkan Panca Tan Matra dengan Panca Maha Bhuta, penyatuan antara atma dengan dewa, hal ini yang dinamakan Parihartapana, yaitu semua dikembalikan ke asal, memenuhi ujung Sang Hyang Astalingga, manunggal pada Dia, dinamakan Bapak-Ibu dari Bayu (nafas), Sabda (suara), Idhep (pikiran), disucikan oleh Sang Hyang Mrtyunjaya, menjadi Sang Hyang Kala Mrtyu.

Melesatlah Sang Hyang Atma menuju Sang Hyang Asta Lingga, menempatkan diri di Antasunya. Matilah maharaja Yudhistira, bagaikan tidur badan maharaja Yudhistira. Melihat hal tersebut, raja Candra Bairawa terdiam, lalu menyusup ke dalam Asta Lingga, ditariklah Sang Hyang Tiga Sadhana, ditahanlah dunia oleh Candra Bairawa, bersatu dengan Sang Hyang Tri Rahasyajanana, sehingga Atma diikat dengan kuat, dikembalikan pada tempatnya semula. Kemudian Yudhistira siuman.

Selanjutnya giliran maharaja Candra Bairawa yang melakukan konsentrasi, dipasangilah intisari kekuatan serta memutar batin, sampai menembus kekosongan sampai ke dasar bumi, melesatlah Sang Hyang Atma melalui niratmaka, dan akhirnya tiba di alam Siwa, kemudian menghadap Bhatara Guru. Candra Bairawa menyampaikan kepada dewa Siwa, bahwa dia sedang mengadu kekuatan spiritual dengan maharaja Hastina yaitu Yudhistira, dan memohon kepada dewa Siwa untuk tidak memberitahukan tentang persembunyiannya di alam Siwa dan Candra Bairawa mohon kehadapan Siwa untuk dapat masuk kealam Sunyaloka.

Yudhistira melakukan semedhi untuk dapat menangkap atma Candra Bairawa, tetapi tidak dapat diketemukan oleh Yudhistira. Yudhistira menghadap Bhatara Guru untuk menanyakan tentang keberadaan Candra Bairawa. Bhatara Siwa Guru menjelaskan perihal Candra Bairawa, bahwa Candra Bairawa awalnya adalah Sang Hyang Adhi Budha namanya, hanya melaksanakan Yoga Sanyasa, tidak ada Karma Sanyasa pada dirinya, hanya Nisreyasa (Nirwana) yang diyakininya. Kemudian Bhatara Guru mempersilahkan Yudhistira mencari atma Candra Bairawa ke Sunyaloka. Pada akhirnya Candra Bairawa mengakui keunggulan ajaran Karma Sanyasa. Yudhistira kemudian mengajarkan tentang ajaran Siwa-Buddha yaitu perpaduan antara Karma Sanyasa dengan Yoga Sanyasa.

Uraian di atas dapat disimpulkan bahwa, wacana moksa menurut kakawin Candra Bairawa disampaikan melalui dialog, baik dialog antara Werkodara dengan Candra Bairawa, antara Kresna dengan Candra Bairawa, antara Yudhistira dengan Siwa Guru (Bhatara guru), antara Yudhistira dengan Candra Bairawa.

Inti dari ajaran Candra Bairawa adalah pelaksanaan Catur Yoga Marga secara utuh dan tidak boleh terpisah-pisahkan. Dari konsep catur yoga marga ini melahirkan ajaran karma sanyasa yang mencakup karma marga, bhakti marga, jnana marga dan yoga marga, sedangkan mereka yang hanya mengambil jnana marga dan yoga marga melahirkan konsep ajaran yoga sanyasa. Dari kedua konsep tersebut yang diperankan oleh tokoh utama Candra Bairawa sebagai tokoh yoga sanyasa dan Yudhistira sebagai tokoh karma sanyasa sama-sama dapat memasuki alam 
moksa dengan melepas roh beliau, Yudhistira menuju alam Siwa sedangkan jalan yang ditempuh oleh Candra Bairawa adalah jnana marga dengan yoga marga. Pada intinya sama-sama $S a-$ myajnana, yaitu memiliki ilmu pengetahuan yang benar.

\section{PENUTUP}

Konsep-konsep ajaran agama Hindu tertuang dalam kakawin Candra Bairawa, yakni meliputi: wacana konsep surga yaitu di dalam kakawin Candra Bairawa, melalui analogi atau metafora, melalui dialog antar tokoh dalam cerita, serta pemerian konsep. Candra Bairawa mengajak rakyatnya menuju surga dengan jalan Yoga Sanyasa, sedangkan Kresna dan Yudhistira mengajarkan masyarakat Dwarawati dan Astinapura melaksanakan upacāra agama yang lebih menekan- kan pada aspek Karma Sanyasa.

Selanjutnya wacana konsep naraka yakni wacana neraka dalam kakawin Candra Bairawa disampaikan melalui dialog, analogi dan pemerian konsep, Candra Bairawa mempercayai adanya neraka, hanya saja neraka itu tidak jauh dari diri sendiri, baik surga ataupun neraka tidak menjadi tujuan utama di dalam keyakinan Candra Bairawa, melainkan manunggal dengan Sanghyang Addhi Budha.

Kemudian wacana konsep moksa menurut kakawin Candra Bairawa disampaikan melalui dialog, baik dialog antara Werkodara dengan Candra Bairawa, antara Kresna dengan Candra Bairawa, antara Yudhistira dengan Siwa Guru (Bhatara guru), antara Yudhistira dengan Candra Bairawa. Inti dari ajaran Candra Bairawa adalah pelaksanaan Catur Yoga Marga secara utuh dan tidak boleh terpisah-pisahkan. •

\section{DAFTAR PUSTAKA}

Agastia, IB Gede, 1994, Ida Pedanda Made Sidemen Pengarang Besar Bali Abad ke 20. Denpasar: Yayasan Dharma Sastra.

2002, Kawi dan Kawi. Makalah Simposium Pertama Sastra Daerah Se-Indonesia di UNS Surakarta.

Arifin, E, Zaenal, 2000, Dasar-Dasar Penulisan Karangan Ilmiah Lengkap dengan Kaidah Bahasa Indonesia yang Benar. Jakarta: Grasindo.

Arikunto, Suharsimi, 2002, Prosedur Penelitian Suatu Pendekatan Praktis. Jakarta: PT. Rineka Cipta. Bagus, Lorens. 2002, Kamus Filsafat. Jakarta: PT. Gramedia Pustaka Utama.

Bertens, 1997, Etika. Jakarta, PT. Gramedia Pustaka Utama.

Cholid, Nurmuko dkk, 1997, Metode Penelitian. Jakarta: Bumi Aksara.

Cudamani, 1990, Pengantar Agama Hindu Untuk Perguruan Tinggi. Jakarta: Yayasan Dharma Sarathi. Dardji Dharmodiharjo dkk, 1994, Bahan Penataran Pendidikan Moral Pancasila. Depdikbud.

Ghoni, Muhamad Djunaedi, (tt), Nilai Pendidikan. Surabaya; Usaha Nasional.

Hutagalung, M.S, 1995, Djalan Tak Ada Ujung Moghtar Lubis. Jakarta; PT. Gunung Agung.

Idris, H, Zahara dkk, 1992, Pengantar Pendidikan I. Jakarta : PT. Gramedia Widya Sarana Indonesia.

Ilich, Ivan, 2008, Bebaskan Masyarakat Dari Belenggu Sekolah. Jakarta : Yayasan Obor Indonesia.

Jendra, I Wayan, 2008, Tuhan Sudah Mati, Surabaya: Paramita.

Kadjeng, I Nyoman dkk, 2005, Sarasamuscaya, Surabaya: Paramita.

Koentjaraningrat, 1976, Beberapa Pokok Antropologi Sosial. Jakarta: PT. Dian Rakyat. 1991, Metode Penelitian Masyarakat. Jakarta : Gramedia.

Buana, Langgeng, I Made, 2006, Ajaran Siwa-Buddha Dalam Kakawin Nilacandra. Universitas Hindu Indonesia.

Mangunwijaya, Y.B, 1982: Sastra dan Religiusitas. Jakarta: Sinar Harapan.

Margono, S, 2004, Metode Penelitian Pendidikan. Jakarta: PT. Rineka Cipta. 
Moeloeng, dan J. Lexy. 1997, Metodologi Penelitian Kualitatif. Bandung: Remaja Rosda Jaya.

Oka, Punyatmaja, IB, 1994, Cilakrama. Denpasar: Upada Sastra.

PHDI, 2000, Himpunan Keputusan Seminar Kesatuan Tafsir Terhadap Aspek-aspek Agama Hindu I-V.

Pusat Dokumentasi Budaya, 2004, Alih Aksara dan Terjemahan Lontar Kakawin Candra Bairawa, Dinas Kebudayaan Provinsi Bali.

Poerwadarminta, 1994, Kamus Umum Bahasa Indonesia. Jakarta: Balai Pustaka.

Sarwono, Sarlito Wirawan, 2001, Teori-teori Psikologis Sosial. Jakarta : Raja Grafika Persada

Soebandi, Jro Mangku Gde, Ketut, 1988, Babad Warga Brahmana Pandita Sakti Wawu Rawuh, Asalusul, Peninggalan dan Keturunan Danghyang Nirartha. Surabaya: Paramita.

Suamba, IB Putu, 2007, Siwa-Buddha Di Indonesia (ajaran dan perkembangannya). Widya Dharma.

Sudharta dan Punia Atmaja, 2001, Upadeca. Surabaya: Paramita.

Sudharta, Tjok Rai, 2004, Slokantara Uraian Ajaran Etika. Surabaya: Paramita.

Sudirga, Ib dkk, 2004, Widya Dharma Agama Hindu Kelas XI SMA. Ganeca.

Sugiono, Prof. Dr, 2009, Metode Penelitian Kuantitatif dan Kualitatif dan R\&D. Alfabeta Bandung.

Sugriwa, IB, 1978, Penuntun Pelajaran Kakawin. Percetakan Bali: Denpasar.

Sukada, I Made, 1983, Pendekatan Strukturalisme Dalam Sastra Modern. Denpasar: Jurusan Sastra Indonesia, Fak Sas UNUD.

Sukayasa, I Wayan, 2010, Desertasi Geguritan Sucita; Universitas Udayana.

Sura, I Gede, 1991, Pengantar Tattwa Darsana. Departemen Agama, Direktorat Bimbingan Masyarakat Hindu dan Budha.

Sura, I Gede, 2002, Kamus Istilah Agama Hindu. Pemerintah Provinsi Bali.

Titib, I Made, 2003, Teologi dan Simbol-simbol dalam Agama Hindu. Surabaya: Paramita.

Titib, I Made, 2006, Svarga, Neraka, Moksa dalam Svargarohanaparva. Surabaya; Paramita.

Zoetmulder, P.J, 1985, Kalangwan Sastra Jawa Kuno Selayang Pandang, Djambatan. 